\title{
The hyperinsulinemia produced by concanavalin A in rats is opioid- dependent and hormonally regulated
}

\section{J. Francisco-DoPrado, J.E. Zambelli, M.H. Melo-Lima and G. Ribeiro-DaSilva}

\author{
Departamento de Farmacologia, Faculdade de Ciências Médicas, \\ Universidade Estadual de Campinas, Campinas, SP, Brasil
}

\section{Correspondence}

G. Ribeiro-DaSilva

Departamento de Farmacologia

Faculdade de Ciências Médicas UNICAMP

Caixa Postal 6111

13083-970 Campinas, SP

Brasil

Fax: 55 (019) 289-2968

E-mail: ribersil@uol.com.br

Part of Master's theses presented by J.E. Zambelli and M.H. Melo-Lima to the Departamento de Farmacologia, Faculdade de Ciências Médicas,

Universidade Estadual de Campinas. Some of the results of this study were presented at the XVIII

Congreso Latinoamericano de Ciencias Fisiológicas, Montevideo,

Uruguay, April 12-16, 1994.

Research supported by FAEP/ UNICAMP (No. 1021/90). Publication supported by FAPESP. $\ldots \ldots \ldots \ldots \ldots \ldots \ldots$

Received October 28, 1997 Accepted February 27, 1998 $\ldots \ldots \ldots \ldots \ldots \ldots \ldots$

\section{Abstract}

The present study examines the effect of concanavalin A (Con A) on the blood insulin and glucose levels of rats. Male and female rats treated with Con A $(62.5-500 \mu \mathrm{g} / \mathrm{kg})$ for three days showed a dose- and time-dependent hyperinsulinemia that lasted more than $48 \mathrm{~h}$. Male rats were more sensitive to Con A. Thus, $6 \mathrm{~h}$ after treatment with Con A the circulating insulin levels in male rats had increased by $85 \%$ (control: $10.2 \pm 0.9 \mathrm{mU} / \mathrm{l}$ and Con A-treated: $18.8 \pm 1 \mathrm{mU} / \mathrm{l}$ ) compared to only $38 \%$ (control: $7.5 \pm 0.2 \mathrm{mU} / \mathrm{l}$; Con A-treated: $10.3 \pm \mathrm{mU} / \mathrm{l}$ ) in females. An identical response was seen after $12 \mathrm{~h}$. Con A $(250 \mu \mathrm{g} / \mathrm{kg})$ produced time-dependent hypoglycemia in both sexes but more pronounced in males. There was no correlation between the hypoglycemia and hyperinsulinemia described above. The Con A-induced hyperinsulinemia in rats of both sexes was abolished in gonadectomized animals (intact males: $+101 \pm 17 \%$ vs orchiectomized males: $-5 \pm 3 \%$; intact females: $+86 \pm 23 \%$ vs ovariectomized females: $-18 \pm 7.2 \%$ ). Pretreating intact male and female rats with human chorionic gonadotropin also significantly inhibited the Con A-induced hyperinsulinemia. Estradiol $(10 \mu \mathrm{g} / \mathrm{kg}$, im) significantly blocked the Con A-induced increase in circulating insulin in male rats $(101 \pm 17 \%$ for controls vs $32 \pm 5.3 \%$ for estradiol-treated animals, $\mathrm{P}<0.05$ ) while testosterone $(10 \mathrm{mg} / \mathrm{kg}, \mathrm{im})$ had no similar effect on intact female rats. Pretreating Con A-injected rats with opioid antagonists such as naloxone (1 mg/ $\mathrm{kg}, \mathrm{sc})$ and naltrexone $(5 \mathrm{mg} / \mathrm{kg}, \mathrm{sc})$ blocked the hyperinsulinemia produced by the lectin in males (control: $+101 \pm 17 \%$ vs naloxonetreated: $+5 \pm 14 \%$, or naltrexone-treated: $-23 \pm 4.5 \%$ ) and females (control: $+86 \pm 23 \%$ vs naloxone-treated: $+21 \pm 20 \%$, or naltrexonetreated: $-18 \pm 11 \%$ ). These results demonstrate that Con $\mathrm{A}$ increases the levels of circulating insulin in rats and that this response is opioiddependent and hormonally regulated.
Key words - Concanavalin A

- Hyperinsulinemia

- Blood glucose alterations

- Sex hormones

- Endogenous opioids

- Canatoxin

Can 


\section{Introduction}

Plant lectins are proteins capable of binding to carbohydrates on mammalian cells and membranes. Such binding can lead to a variety of effects including cell agglutination (1), modification of enzymes or receptors on the cell surface (2-5), stimulation of cell growth $(6,7)$, and various hormone-like responses $(8,9)$.

Concanavalin A (Con A) is a glucose/ mannose-binding plant lectin isolated from jack bean (Canavalia ensiformis) seeds that binds extensively to mammalian cell surfaces (10) and exhibits multiplein vitro insulin-like effects $(11,12)$. Thus, Con A stimulates glucose oxidation and hexose transport (13), inhibits epinephrine-stimulated lipolysis in isolated adipocytes (14) and inhibits insulin binding to intact adipocytes and liver cell membranes $(12,15)$.

Lectins and related toxic seed proteins may share common pharmacological and biochemical properties, as has been shown for seeds of the castor bean (Ricinus communis), the jequiriti bean(Abrus precatorius) (16) and kintoki beans (Phaseolus vulgaris) (17).

Although Con A and canatoxin (CNTX), a toxic protein isolated from Canavalia ensiformis seeds, are structurally distinct (for a review, see Ref. 18), both substances induce platelet aggregation $(19,20)$, trigger histamine secretion from peritoneal mast cells (21-23), and induce paw edema $(24,25)$ and neutrophil chemotaxis in the peritoneal cavity of rats (26-28).

The administration of CNTX to rats raises circulating insulin levels (29) and produces hormonally regulated blood glucose alterations (30). Several of the effects described for this toxin $(31,32)$, including hyperinsulinemia (29), are modulated by the endogenous opioid system. A long-lasting hypoglycemia is the main effect produced by CNTX in rats $(33,34)$. The increased insulin levels and consequent hypoglycemia seen in these animals suggested that the toxin may act upon pancreatic islet B-cells. This hypothesis has been confirmed by the observation that isolated rat pancreatic islets secrete insulin when exposed to CNTX (35).

The present study examines the effect of Con A on the blood insulin and glucose levels of rats. The involvement of opioids and a possible sex-related, hormone-dependent susceptibility to the effects of the toxin were also investigated.

\section{Material and Methods}

Male and female Wistar rats (200-250 g) were used. All experiments were done between 1:00 p.m. and 4:00 p.m. using rats that had been individually caged with free access to food and water for at least $24 \mathrm{~h}$ beforehand.

Con A (Sigma Chemical Co., St. Louis, MO) was dissolved in $0.1 \mathrm{M}$ phosphate buffer, $\mathrm{pH}$ 7.0, and administered sc to the animals every $24 \mathrm{~h}$ for three days. In most experiments, the dose of Con A was $250 \mu \mathrm{g}$ / $\mathrm{kg}$. At the desired time, blood samples were obtained from one control and one test group by cardiac puncture under chloral hydrate $(350 \mathrm{mg} / \mathrm{kg}$, ip) anesthesia.

Insulin levels were measured by radioimmunoassay (RIA) using a commercial kit (Pharmacia Diagnostics). The assays were performed in duplicate using 100- $\mu$ l serum aliquots. The intra- and inter-assay coefficients of variation were $\leq 5.8 \%$ and $\leq 6.5 \%$, respectively. The results are reported as $\mathrm{mU}$ of insulin per liter of serum or as a percent of basal levels (taken as 100\%). Blood glucose levels were determined using a glucose oxidase method (36) and the results are reported as mmol glucose per liter of blood.

Different groups of rats (six animals per group) were submitted to one of the following protocols: group 1 consisted of intact males and females injected with Con A or vehicle. Group 2 consisted of gonadectomized males and females injected with Con A or vehicle solution three weeks after surgery. Group 3 consisted of intact males and 
females pretreated with human chorionic gonadotropin (hCG) in accordance with the schedule used by Reich et al. (37). The animals were pretreated with hCG (40 IU/kg, im) over a three-day period. Treatment with Con A or vehicle was initiated $6 \mathrm{~h}$ after the first injection of hCG. Group 4 consisted of intact males and females pretreated every 72 $\mathrm{h}$ with three injections of $0.5 \mathrm{ml}$ of depoestradiol $(10 \mu \mathrm{g} / \mathrm{kg}$ in corn oil, im) or depotestosterone $(10 \mathrm{mg} / \mathrm{kg}$ in corn oil, im), respectively. In both cases, the schedule described by Pomerantz et al. (38) was used. Treatment with Con A or vehicle solution was started on the eighth day of hormonal pretreatment. Group 5 consisted of intact males and females pretreated with naloxone
$(1 \mathrm{mg} / \mathrm{kg}, \mathrm{sc})$ or naltrexone $(5 \mathrm{mg} / \mathrm{kg}, \mathrm{sc}) 20$ min before the administration of Con A or vehicle solution.

The results are reported as means \pm SEM. Comparison of the means, reported as percent variation, was performed using the Kruskal-Wallis test. Other means were compared by the Student unpaired t-test. In both cases, a $P$ value $\leq 0.05$ was considered to be significant.

\section{Results}

Male and female rats treated chronically with Con A $(62.5-500 \mu \mathrm{g} / \mathrm{kg})$ developed hyperinsulinemia. Tables 1 and 2 show that the phenomenon was dose- and time-depend-

Table 1 - Dose dependence of the hyperinsulinemia induced by Con A in male and female rats.

Con A was injected sc every $24 \mathrm{~h}$ over a three-day period. Blood samples for insulin determinations were obtained $24 \mathrm{~h}$ after the last Con $\mathrm{A}$ administration. The results are reported as the mean $\pm \mathrm{SEM}$ for six rats per group. ${ }^{*} \mathrm{P} \leq 0.05$ compared to the control group (Student unpaired $t$-test).

\begin{tabular}{|c|c|c|c|c|c|c|}
\hline \multirow[t]{3}{*}{ Con A $(\mu g / k g)$} & \multicolumn{3}{|c|}{ Females } & \multicolumn{3}{|c|}{ Males } \\
\hline & \multicolumn{3}{|c|}{ Serum insulin (mU/l) } & \multicolumn{3}{|c|}{ Serum insulin (mU/l) } \\
\hline & Control & Treated & $\Delta \%$ & Control & Treated & $\Delta \%$ \\
\hline 62.5 & $8.4 \pm 0.9$ & $9.5 \pm 1.0$ & +13 & $10.2 \pm 0.5$ & $12.1 \pm 2.1^{*}$ & +19 \\
\hline 125 & $8.0 \pm 0.7$ & $10.7 \pm 0.6^{*}$ & +34 & $9.4 \pm 1.0$ & $12.0 \pm 0.3^{*}$ & +27 \\
\hline 250 & $8.2 \pm 0.2$ & $15.3 \pm 0.3^{*}$ & +86 & $8.3 \pm 0.2$ & $16.8 \pm 0.7^{*}$ & +101 \\
\hline 500 & $9.0 \pm 1.0$ & $12.1 \pm 0.5^{*}$ & +34 & $11.2 \pm 0.6$ & $14.2 \pm 0.2^{*}$ & +27 \\
\hline
\end{tabular}

Table 2 - Time course of the hyperinsulinemia induced by Con A in male and female rats.

Con A $(250 \mu \mathrm{g} / \mathrm{kg})$ was injected sc every $24 \mathrm{~h}$ over a three-day period. Blood samples for insulin determinations were withdrawn at the times indicated after the last Con A administration. Data are reported as the mean \pm SEM for six rats per group. ${ }^{*} \mathrm{P} \leq 0.05$ compared to the control group (Student unpaired $t$-test).

\begin{tabular}{|c|c|c|c|c|c|c|}
\hline \multirow[t]{3}{*}{ Time (h) } & \multicolumn{3}{|c|}{ Females } & \multicolumn{3}{|c|}{ Males } \\
\hline & \multicolumn{3}{|c|}{ Serum insulin (mU/l) } & \multicolumn{3}{|c|}{ Serum insulin $(\mathrm{mU} / \mathrm{l})$} \\
\hline & Control & Treated & $\Delta \%$ & Control & Treated & $\Delta \%$ \\
\hline 1 & $10.2 \pm 1.0$ & $11.4 \pm 1.0$ & +12 & $9.2 \pm 0.2$ & $11.4 \pm 0.4^{*}$ & +24 \\
\hline 3 & $12.2 \pm 0.1$ & $14.6 \pm 0.2^{*}$ & +20 & $8.3 \pm 0.9$ & $11.3 \pm 0.3^{*}$ & +35 \\
\hline 6 & $7.5 \pm 0.2$ & $10.3 \pm 0.9^{*}$ & +38 & $10.2 \pm 0.9$ & $18.8 \pm 1.0^{*}$ & +84 \\
\hline 12 & $9.1 \pm 1.0$ & $15.1 \pm 1.0^{*}$ & +66 & $11.4 \pm 0.2$ & $25.6 \pm 1.0^{*}$ & +124 \\
\hline 24 & $8.2 \pm 0.2$ & $15.3 \pm 0.3^{*}$ & +86 & $8.3 \pm 0.2$ & $16.8 \pm 0.7^{*}$ & +101 \\
\hline 48 & $10.5 \pm 0.9$ & $16.0 \pm 0.4^{*}$ & +52 & $9.7 \pm 0.2$ & $14.6 \pm 0.9^{*}$ & +51 \\
\hline
\end{tabular}




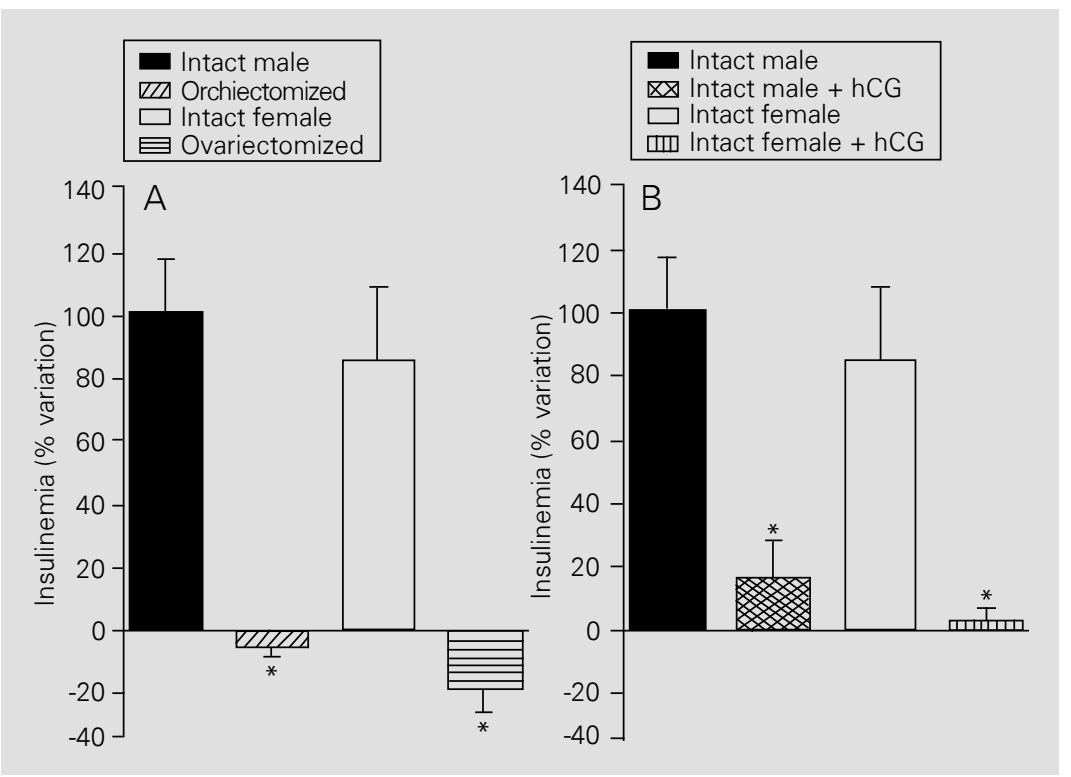

Figure 1 - Castration (A) and pretreatment with human chorionic gonadotropin (hCG) (B) inhibit the hyperinsulinemia produced by Con A in intact male and female rats. Con A (250 $\mu \mathrm{g} / \mathrm{kg}$ ) was injected $s c$ every $24 \mathrm{~h}$ over a three-day period. Blood samples for insulin determinations were obtained $24 \mathrm{~h}$ after the last administration of Con A or vehicle. Each bar represents the mean \pm SEM for six rats per group. The values for the treated animals are reported as the percent variation relative to the vehicle-treated controls taken as $100 \%$ (males $8.3 \mathrm{mU} / \mathrm{l}$ and females $8.2 \mathrm{mU} / \mathrm{l}$ ). Gonadectomized males and females were injected with Con A or vehicle three weeks after surgery. Intact males or females received hCG (40 $\mathrm{IU} / \mathrm{kg}$ ) im every $24 \mathrm{~h}$ over a three-day period. Treatment with Con A or vehicle was started 6 $h$ after the first injection of hCG. ${ }^{*} P \leq 0.05$ compared to intact $(A)$ or non-pretreated $(B)$ rats (Kruskal-Wallis test).

Figure 2 - Effect of pretreatment with estradiol and testosterone on the hyperinsulinemia produced by Con $A$ in intact male and female rats. Male rats were pretreated with estradiol $\left(\mathrm{OE}_{2}\right.$, $10 \mu \mathrm{g} / \mathrm{kg}$ ) and female rats with testosterone ( $\mathrm{T}, 10 \mathrm{mg} / \mathrm{kg}$ ). In both cases, the hormone was injected im every 72 h. Treatment with Con A $(250 \mu \mathrm{g} / \mathrm{kg})$ or vehicle was started on the eighth day of hormonal pretreatment. The values are reported as the percent change relative to the vehicle-treated controls taken as $100 \%$ (males: $8.3 \mathrm{mU} / \mathrm{I}$ and females: $8.3 \mathrm{mU} / \mathrm{l}) .{ }^{*} \mathrm{P} \leq 0.05$ compared to non-pretreated rats (Kruskal-Wallis test).

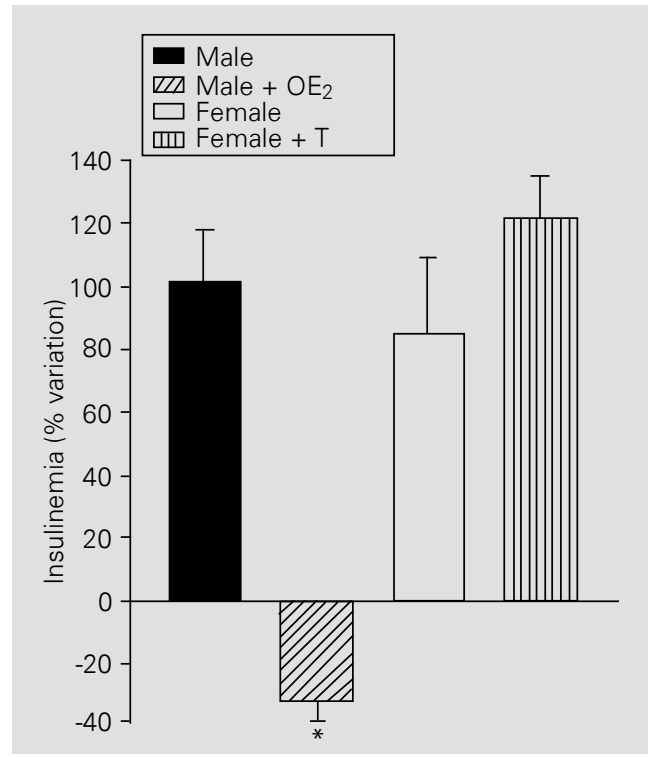

ent, respectively, and that it lasted for more than $48 \mathrm{~h}$.

Male rats were more sensitive to the hyperinsulinemic effect of Con A (Table 2). Thus, $6 \mathrm{~h}$ after the treatment with Con A $(250 \mu \mathrm{g} / \mathrm{kg})$, the circulating insulin levels in males had increased by $85 \%$ compared to only $38 \%$ in females. An identical situation was observed at $12 \mathrm{~h}$ (males, $+124 \%$; females, $+66 \%$ ).

The increase in circulating insulin levels produced by Con A in intact male and female rats was blocked when the animals were orchiectomized and ovariectomized, respectively. Similarly, pretreating intact male and female rats with hCG significantly inhibited the Con A-induced hyperinsulinemia (Figure 1).

Figure 2 shows that pretreating intact male rats with estradiol significantly inhibited the Con A-induced hyperinsulinemia while there was no significant change in intact female rats pretreated with testosterone.

Pretreating rats of both sexes with the opioid antagonists naloxone and naltrexone inhibited the hyperinsulinemic effect of Con A (Figure 3).

Male and female rats chronically treated with Con A $(250 \mu \mathrm{g} / \mathrm{kg})$ showed a biphasic and time-dependent change in blood glucose levels (Table 3 ). The early phase lasted for approximately $6 \mathrm{~h}$ after the last Con A injection while the late phase continued for up to 24 $h$ and ended by $48 \mathrm{~h}$. In the early phase of the response male rats exhibited hypoglycemia while female rats were hyperglycemic. However, $12 \mathrm{~h}$ after the last treatment with Con A (late phase), a persistent hyperglycemia was detected in males, while in females there was a significant but transient decrease in the circulating glucose levels (18\%). Thus, rats of both sexes exhibited hypoglycemia but the response was more marked in males.

\section{Discussion}

The present results demonstrate that Con 
A significantly increased the levels of circulating insulin in rats via a mechanism that was opioid-dependent and hormonally regulated. Changes in blood glucose levels were also detected in the lectin-treated rats.

Males were more sensitive than females to the hyperinsulinemic effect of Con A (Table 2). In addition, the increase in plasma insulin levels produced by Con A in rats of either sex completely disappeared in gonadectomized animals (Figure 1A), indicating that sex hormones play an important role in this phenomenon. The hyperinsulinemia produced by Con A was inhibited when rats of either sex were pretreated with hCG (Figure 1B). Since castration is known to elevate the circulating gonadotropin concentrations in male and female animals (39), the increase in insulin produced by Con A also appears to be modulated by these hormones.

Morphine and $B$-endorphin are powerful stimuli for insulin secretion $(40,41)$. Several investigators (42-44) have demonstrated that the effects of opioid-like peptides, in addition to being sex related, are also hormonally regulated. Our findings that the pretreatment of Con A-injected rats with opioid antagonists such as naloxone and naltrexone (45) completely blocked the hyperinsulinemia induced by this lectin (Figure 3 ) are consistent with the foregoing reports.

As described for CNTX $(18,29,35)$, the Con A-induced hyperinsulinemia may also have resulted from a secretory action of this lectin on pancreatic B-cells. However, this hypothesis was not supported by our data showing that male rats are more sensitive than females to Con A-induced hyperinsulinemia (Table 2) since it is well known that estrogens (46) and progesterone (47) intensify the secretory response of B-cells. Estradiol significantly blocked Con A-induced increase in plasma insulin levels in male rats while no significant change was seen in intact females treated with testosterone. This is an unusual finding since testosterone generally reduces the secretory re- sponse of pancreatic $\beta$-cells in response to glucose (48).

The regulatory mechanism that maintains the systemic glucose balance involves hormonal, neural, and autoregulatory factors. Hypoglycemia is only an indication that the rate of glucose efflux from the circulation exceeds that of glucose influx. The time course of the hyperinsulinemia (Table 2) and blood glucose alterations (Table 3 ) in-

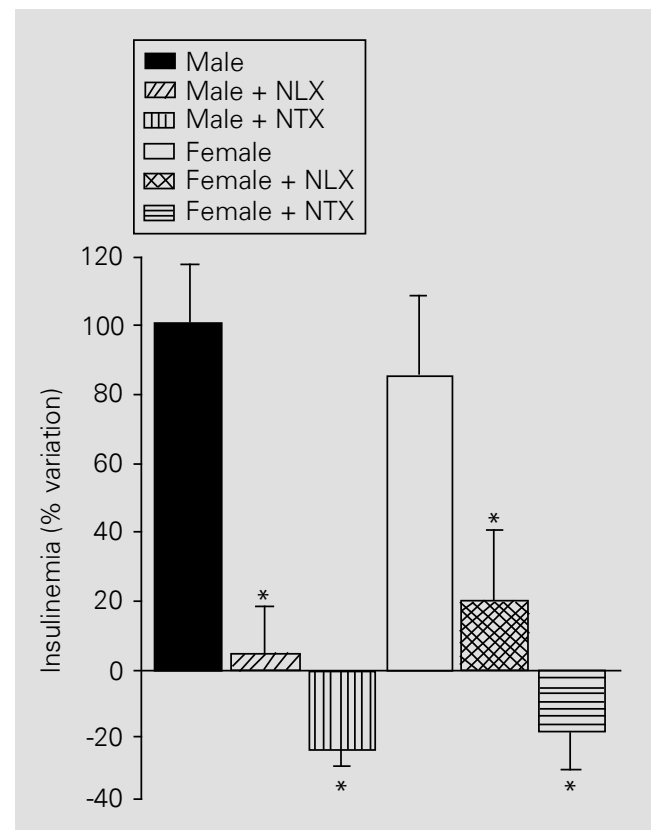

Figure 3 - Naloxone and naltrexone inhibit the hyperinsulinemia induced by Con $A$ in rats. Intact male and female rats were pretreated im with naloxone (NLX, $1 \mathrm{mg} / \mathrm{kg}$ ) or naltrexone (NTX, 5 $\mathrm{mg} / \mathrm{kg}) 20 \mathrm{~min}$ before the injection of Con A $(250 \mu \mathrm{g} / \mathrm{kg})$ or vehicle. The animals were bled for insulin determination $24 \mathrm{~h}$ after the last treatment with Con A or vehicle. The values are reported as the percent change relative to vehicle-treated controls taken as $100 \%$ (males, $8.3 \mathrm{mU} / \mathrm{l}$ and females $8.2 \mathrm{mU} / \mathrm{l}) .{ }^{*} \mathrm{P} \leq 0.05 \mathrm{com}-$ pared to non-pretreated rats (Kruskal-Wallis test).
Table 3 - Time course of the blood glucose alterations induced by Con A in male and female rats.

Con A $(250 \mu \mathrm{g} / \mathrm{kg})$ was injected sc every $24 \mathrm{~h}$ over a three-day period. Blood samples for glucose determinations were obtained at the times indicated after the last Con A administration. The results are reported as the mean \pm SEM for six rats per group. ${ }^{*} P \leq 0.05$ compared to the control group (Student unpaired $t$-test).

\begin{tabular}{|c|c|c|c|c|c|c|}
\hline \multirow[t]{3}{*}{ Time (h) } & \multicolumn{3}{|c|}{ Females } & \multicolumn{3}{|c|}{ Males } \\
\hline & \multicolumn{3}{|c|}{ Blood glucose $(\mathrm{mmol} / \mathrm{l})$} & \multicolumn{3}{|c|}{ Blood glucose (mmol/l) } \\
\hline & Control & Treated & $\Delta \%$ & Control & Treated & $\Delta \%$ \\
\hline 1 & $9.0 \pm 0.2$ & $10.6 \pm 0.2^{*}$ & +18 & $10.2 \pm 0.3$ & $8.5 \pm 0.2^{*}$ & -17 \\
\hline 3 & $8.8 \pm 0.4$ & $10.8 \pm 0.3^{*}$ & +23 & $9.0 \pm 0.1$ & $6.0 \pm 0.3^{*}$ & -33 \\
\hline 6 & $9.1 \pm 0.1$ & $10.8 \pm 0.1^{*}$ & +19 & $8.9 \pm 0.2$ & $7.4 \pm 0.2^{*}$ & -17 \\
\hline 12 & $8.8 \pm 0.2$ & $7.2 \pm 0.1^{*}$ & -18 & $8.1 \pm 0.1$ & $9.4 \pm 0.1^{*}$ & +16 \\
\hline 24 & $8.4 \pm 0.2$ & $8.6 \pm 0.1$ & -2 & $10.5 \pm 0.1$ & $13.6 \pm 0.2^{*}$ & +29 \\
\hline 48 & $9.0 \pm 0.3$ & $8.1 \pm 0.5$ & -10 & $11.0 \pm 0.3$ & $10.6 \pm 0.1$ & -4 \\
\hline
\end{tabular}


duced by Con A in rats of both sexes was not positively correlated with each other, indicating that these two responses were not necessarily related. However, it is interesting to note that the blood glucose alterations induced by the lectin in rats, like hyperinsulinemia, are sex-related, hormonally regulated and opioid-dependent (49), suggesting that a common pathophysiological mechanism is involved in these events.

The present data demonstrate that Con A significantly increased blood insulin levels in rats via an opioid-dependent, hormonally regulated pathway. Exactly how sex hormones and opioids are involved in this hyperinsulinemia is currently under investigation in our laboratory.

\section{Acknowledgments}

The statistical advice of Prof. Aquiles E. Pietrabuena and the editorial assistance of Dr. Stephen Hyslop are gratefully acknowledged. We also thank Dr. Ivani Aparecida Desouza for her help in organizing figures and tables.

\section{References}

1. Rapin AMC \& Burger MM (1974). Tumor cell surfaces: general alterations detected by agglutinins. Advances in Cancer Research, 20: 1-91.

2. Carroway CA \& Carroway KL (1976). Concanavalin $A$ : a perturbation of membrane enzymes of mammary gland. Journal of Supramolecular Structure, 4: 121-126.

3. Novogrodsky A (1972). Concanavalin A stimulation of rat lymphocyte ATPase. Biochimica et Biophysica Acta, 266: 343349.

4. Riordan J \& Slavick M (1974). Interactions of lectins with membrane glycoproteins effects of Con A on 5' nucleotidase. Biochimica et Biophysica Acta, 373: 356-360.

5. Young ME \& Moscarello MA \& Riordan JR (1976). Concanavalin A binding to membranes of Golgi apparatus and resultant modifications of galactosyl transferase activity. Journal of Biological Chemistry, 251: 5860-5865

6. Greaves M \& Janossy G (1972). Elicitation of selective $T$ and $B$ lymphocyte responses by cell surface binding ligands. Transplantation Reviews, 11: 87-130.

7. Novogrodsky A \& Katchaski E (1971). Lymphocyte transformation induced by concanavalin $A$ and its reversal by alfamethyl-D-glucoside. Biochimica et Biophysica Acta, 228: 579-583

8. Cuatrecasas P \& Tell GPE (1973). Insulinlike activity of Con $A$ and wheat germ agglutinin - direct interaction with insulin receptors. Proceedings of the National Academy of Sciences, USA, 70: 485-489.

9. Solomon SS, King LE \& Hashimoto K (1975). Studies of the biological activity of insulin, cyclic nucleotides and concanavalin A in the isolated fat cell. Hormone and Metabolism Research, 7: 297-304.

10. Sharon N \& Lis H (1972). Lectins: cellagglutinating and sugar-specific proteins. Science, 177: 949-959.

11. Maier V, Schneider C, Schatz H \& Pfeiffer EE (1975). Interactions of concanavalin A with isolated pancreatic islets. HoppeSeyler's Zeitschrift für Physiologische Chemie, 356: 887-893.

12. Cuatrecasas $P$ (1973). Interaction of concanavalin $A$ and wheat germ agglutinin with insulin receptor of fat cells and liver. Journal of Biological Chemistry, 248: 3528-3534

13. Czech MP, Lawrence JC \& Lynn WS (1974). Activation of hexose transport by concanavalin A in isolated brown fat cells. Journal of Biological Chemistry, 249: 7499-7505

14. Czech MP, Lynn DG \& Lynn WS (1973). Cytochalasin B-sensitive 2-deoxy-D-glucose transport in adipose cell ghosts. Journal of Biological Chemistry, 248: 3636-3641.

15. Livingston JN \& Purvis BJ (1980). Effects of wheat germ agglutinin on insulin binding and insulin sensitivity of fat cells. American Journal of Physiology, 238: E267-E275

16. Olsnes S, Saltvedt E \& Phil A (1974). Isolation and comparison of galactose-binding lectins from Abrus precatorius and Ricinus communis. Journal of Biological Chemistry, 249: 803-810.

17. Hamaguchi $Y$, Yagi N, Nishino A, Mochizuki T, Mizukami T \& Miyoshi M
(1977). The isolation and characterization of a lethal protein from kintoki beans (Phaseolus vulgaris). Journal of Nutrition Science and Vitaminology, 23: 525-534.

18. Carlini CR \& Guimarães JA (1991). Plant and microbial toxic proteins as hemilectins: emphasis on canatoxin. Toxicon, 29: 791-806.

19. Bellville JS, William BF \& Gary F (1979). A method for investigating the role of calcium in the shape change, aggregation and serotonin release of rat platelets. Journal of Physiology, 297: 289-296.

20. Carlini CR, Guimarães JA \& Ribeiro JMC (1985). Platelet release reaction and aggregation induced by canatoxin, a convulsant protein: evidence for the involvement of the lipoxygenase pathway. British Journal of Pharmacology, 84: 551-560.

21. Grassi-Kassisse DM \& Ribeiro-DaSilva $G$ (1992). Canatoxin triggers histamine secretion from rat peritoneal mast cells. Agents and Actions, 37: 204-209.

22. Shores AJ \& Mongar JL (1980). Modulation of histamine secretion from Con Aactivated rat mast cells by phosphatidylserine, calcium, cAMP, pH and metabolic inhibitors. Agents and Actions, 10: 131137.

23. Sullivan TJ, Greene, WC \& Parker CW (1975). Concanavalin A-induced histamine release from normal rat mast cells. Journal of Immunology, 115: 278-282.

24. Bento CAM, Cavada BS, Oliveira JTA Moreira RA \& Barja-Fidalgo C (1993). Rat paw edema and leukocyte immigration induced by plant lectins. Agents and Actions, 38: 48-54. 
25. Benjamin CF, Carlini CR \& Barja-Fidalgo $C$ (1992). Pharmacological characterization of rat paw edema induced by canatoxin, the toxic protein from Canavalia ensiformis (jack bean) seeds. Toxicon, 30: 879885.

26. Barja-Fidalgo $C$, Carlini CR, Guimarães JA, Flores CA, Cunha FQ \& Ferreira SH (1992). Role of resident macrophages in canatoxin-induced in vivo neutrophil migration. Inflammation, 16: 1-12.

27. Ghazaleh FA, Araújo CF, Barja-Fidalgo C \& Carlini CR (1992). Canatoxin induces activation on mice peritoneal macrophages. Brazilian Journal of Medical and Biological Research, 25: 1033-1035.

28. Shier WT (1975). Concanavalin A induced inflammation. Advances in Experimental Biology and Medicine, 55: 347-348.

29. Ribeiro-DaSilva G \& Prado JF (1993). Increased insulin circulating levels induced by canatoxin in rats. Toxicon, 31: 11311136.

30. Pires-Barbosa R \& Ribeiro-DaSilva G (1989). Sex-related canatoxin-induced blood glucose alterations in the rat. Brazilian Journal of Medical and Biological Research, 22: 1507-1513.

31. Ribeiro-DaSilva G, Pires-Barbosa R \& Carlini CR (1989). Effect of canatoxin on the circulating levels of gonadotropins and prolactin in rats. Brazilian Journal of Medical and Biological Research, 22: 387-395.

32. Ribeiro-DaSilva G, Prado JF, Collares CB \& Siste-Campos M (1992). Further studies on the hypoxia produced by canatoxin in rats. Brazilian Journal of Medical and Biological Research, 25: 849-852.

33. Ribeiro-DaSilva G, Carlini CR, PiresBarbosa R \& Guimarães JA (1986). Blood glucose alterations induced in rats by canatoxin, a protein isolated from jack bean (Canavalia ensiformis) seeds. Toxicon, 24: 775-782.

34. Ribeiro-DaSilva G, Collares CB, Grassi DM, Prado JF, Zappellini A \& Carlini CR (1989). Alterations in rat carbohydrate metabolism induced by canatoxin in rats as a probable consequence of primary hypoxia. Brazilian Journal of Medical and Biological Research, 22: 1405-1413.

35. Barja-Fidalgo C, Guimarães JA \& Carlini CR (1991). Canatoxin, a plant protein, induces insulin release from rat isolated pancreatic islets. Endocrinology, 128: 675679.

36. Trinder $P$ (1969). Determination of glucose in blood using glucose oxidase with an alternative oxygen acceptor. Annual of Clinical Biochemistry, 6: 24-30.

37. Reich $R$, Kohen $F$, Slager $R$ \& Tsafriri $A$ (1985). Ovarian lipoxygenase activity and its regulation by gonadotropin in the rat. Prostaglandins, 30: 581-590.

38. Pomerantz $K$, Maddox $Y$, Maggi $F$ \& Ramwell P (1980). Sex and hormonal modification of 6-keto-PGF1 $\alpha$ release by rat aorta. Life Sciences, 27: 1233-1236.

39. MacCann SM (1974). Endocrinology. In: Greep RD \& Astwood EB (Editors), Handbook of Physiology. Saunders, London, 711-731.

40. Ipp E, Dobbs R \& Unger RH (1978). Morphine and ß-endorphin influence the secretion of the endocrine pancreas. $\mathrm{Na}$ ture, 276: 190-191.

41. Ipp E, Schusdziarra V, Harris V \& Unger $\mathrm{RH}$ (1980). Morphine-induced hyperglycemia: role of insulin and glucagon. Endocrinology, 107: 461-463.
42. Frohman LA (1983). Glucoregulation. In: Krieger DT, Brownstein MJ \& Martin JB (Editors), Brain Peptides. Wiley \& Sons, New York, 281-299.

43. Morley JE (1981). The endocrinology of the opiates and opioid peptides. Metabolism, 30: 195-209.

44. Petraglia F, Penalva A, Loccatelli V, Cocchi D, Paneral AE, Genezzani AR \& Muller EE (1982). Effect of gonadectomy and gonadal steroid replacement on pituitary and plasma ß-endorphin levels in the rat. Endocrinology, 111: 1224-1229.

45. Jaffe JH \& Martin WR (1990). Opiod analgesics and antagonists. In: Goodman Gilman A, Rall TW, Nies AS \& Taylor P (Editors), The Pharmacological Basis of Therapeutics. Macmillan Publishing Co., New York, 481-521.

46. Costrini NV \& Kalkhoff RK (1971). Relative effect of pregnancy, estradiol and progesterone on plasma insulin and pancreatic islets insulin secretion. Journal of Clinical Investigation, 50: 992-999.

47. Ashby JP, Ahirling D \& Baird JD (1978). Effect of progesterone on insulin secretion in the rat. Journal of Clinical Investigation, 62: 992-999.

48. Renauld A \& Sverdlik RC (1975). Blood sugar, serum insulin and free fatty acid levels in normal dogs. Sex differences. Acta Physiologica Latinoamericana, 25: 458-461.

49. Zambelli JE (1994). Envolvimento de opióides e de hormônios sexuais nas alterações glicêmicas induzidas por concanavalina A em ratos. Master's thesis, Universidade Estadual de Campinas, Campinas, SP, Brasil. 